\title{
Efek Granisetron Intravena terhadap Perubahan Tekanan Darah pada Seksio Sesarea dengan Anestesi Spinal
}

\author{
Jaya Supriyanto, ${ }^{1,2}$ Iwan Abdul Rachman, ${ }^{2}$ Suwarman ${ }^{2}$ \\ ${ }^{1}$ Pusat Krisis Kesehatan-Kementerian Kesehatan Republik Indonesia, \\ ${ }^{2}$ Departemen Anestesiologi dan Terapi Intensif \\ Fakultas Kedokteran Universitas Padjadjaran/RSUP Dr. Hasan Sadikin Bandung
}

\begin{abstract}
Abstrak
Hipotensi merupakan komplikasi paling sering pada seksio sesarea dengan anestesi spinal. Pencegahan hipotensi dapat dilakukan dengan pemberian cairan, obat-obatan, pengurangan dosis obat anestesi lokal, dan intervensi mekanik. Granisetron sebagai antagonis reseptor 5hydroxytryptamine3 (5HT3) dapat digunakan untuk mencegah hipotensi pada seksio sesarea dengan anestesi spinal. Penelitian ini bertujuan mengetahui pengaruh pemberian granisetron $1 \mathrm{mg}$ intravena terhadap perubahan tekanan darah pada seksio sesarea dengan anestesi spinal. Penelitian ini dilakukan periode Desember 2019-Februari 2020 di RSUP Dr. Hasan Sadikin Bandung. Metode penelitian ini adalah uji klinis tersamar ganda pada 34 pasien ASA II yang menjalani seksio sesarea dengan anestesi spinal. Subjek penelitian dibagi secara acak menjadi 2 kelompok, yaitu kelompok kontrol diberikan $\mathrm{NaCl}$ 0,9\% dan kelompok granisetron diberikan granisetron $1 \mathrm{mg}$ intravena pada 5 menit sebelum anestesi spinal. Tekanan darah diperiksa setiap 1 menit selama 20 menit setelah anestesi spinal, kemudian setiap 2,5 menit sampai operasi selesai. Data dianalisis dengan uji t, Uji Mann Whitney, dan Uji kolmogorov-smirnov, nilai $p<0,05$ dianggap bermakna. Kejadian hipotensi pada kelompok kontrol (79\%) lebih tinggi dari kelompok granisetron (29\%). Penurunan tekanan darah pada kelompok kontrol lebih besar dibanding dengan kelompok granisetron dengan perbedaan signifikan $(\mathrm{p}<0,05)$. Simpulan, pemberian granisetron $1 \mathrm{mg}$ intravena dapat mengurangi kejadian hipotensi pada seksio sesarea dengan anestesi spinal.
\end{abstract}

Kata kunci: Anestesi spinal, hipotensi, granisetron, seksio sesarea

\section{Effect of Intravenous Granisetron on Blood Pressure in Cesarean Section under Spinal Anesthesia}

\begin{abstract}
Hypotension is the most frequent complication in cesarean section with spinal anesthesia. The prevention of hypotension includes fluid and drugs administration, lower local anesthetic doses, and mechanic interventions. Granisetron is a 5HT3 receptor antagonist that can be used to prevent hypotension in cesarean section with spinal anesthesia. This study aimed to determine the effects of intravenous administration of $1 \mathrm{mg}$ granisetron on blood pressure in patients undergoing cesarean section with spinal anesthesia. This study was a double blinded clinical study on 34 patients ASA II undergoing cesarean sections with spinal anesthesia in Dr. Hasan Sadikin General Hospital Bandung, Indonesia, during the period of December 2019 to February 2020. Subjects were divided randomly into 2 groups; a control group that received $0.9 \% \mathrm{NaCl}$ and a granisetron group that received $1 \mathrm{mg}$ intravenous granisetron 5 minutes before spinal anesthesia. Blood pressure was evaluated every minute for 20 minutes after the spinal anesthesia, and then every 2.5 minutes until the surgery was completed. Data were analyzed using t-test, Mann Whitney test, and KolmogorovSmirnov test with $\mathrm{p}$ value $<0.05$ considered significant. Incidence of hypotension in the control group was higher than the granisetron group (79\%vs29\%) with blood pressure decrease significantly higher in the control group ( $\mathrm{p}<0.05)$. Thus, administration of intravenous $1 \mathrm{mg}$ granisetron may reduce the incidence of hypotension in cesarean sections with spinal anesthesia
\end{abstract}

Key words: Cesarean section, granisetron, hypotension, spinal anesthesia

Korespondensi: Jaya Supriyanto, dr., Departemen Anestesiologi dan Terapi Intensif Fakultas Kedokteran Universitas Padjadjaran/Rumah Sakit Umum Pusat Dr. Hasan Sadikin Bandung, Jl. Pasteur No. 38 Bandung 40161, Tlpn 0222038285, Email: jaya.supriyanto@gmail.com 


\section{Pendahuluan}

Anestesi spinal merupakan teknik anestesi yang paling sering digunakan untuk seksio sesarea. Anestesi spinal dipilih karena mudah dilakukan, onset-nya yang cepat, efek blokade sensorik dan motorik lebih kuat dibanding dengan teknik epidural, tingkat kegagalan rendah, kontak fetus dengan obat-obatan minimal, serta bahaya aspirasi minimal. Anestesi spinal dapat menyebabkan komplikasi seperti hipotensi, mual muntah, serta post dural puncture headache (PDPH)., ${ }^{1,2}$ Komplikasi yang paling sering terjadi akibat anestesi spinal adalah hipotensi. ${ }^{1,3-5}$

Kejadian hipotensi pada seksio sesarea dilaporkan sebanyak 80\%. ${ }^{1}$ Angka kejadian hipotensi akibat anestesi spinal pada pasien non obstetrik sebanyak 33\% dan 13\%. ${ }^{4}$ Pada tahun 2015, kejadian hipotensi pada pasien yang menjalani seksio sesarea dengan anestesi spinal di Rumah Sakit Dr. Hasan Sadikin Bandung sebanyak $49 \%{ }^{6}$

Hipotensi yang bermakna ternyata dapat meningkatkan morbiditas pada ibu dan janin. Hipotensi pada anestesi spinal merupakan respons fisiologis akibat blok simpatis yang menyebabkan dilatasi arteri dan vena sehingga aliran darah balik vena menuju jantung menurun, manifestasinya penurunan tekanan darah. ${ }^{1,5}$ Hipotensi pada seksio sesarea dengan anestesi spinal diperberat oleh perubahan fisiologi ibu hamil, yaitu perubahan fisiologi jantung, penurunan aliran darah balik yang diperburuk oleh kompresi vena kava inferior akibat hipertrofi uterus, dan pembentukan sirkulasi kolateral venous plexus di ruang epidural. ${ }^{1,7}$ Penurunan aliran darah balik secara tiba-tiba untuk mencetuskan bezold jarisch reflex (BJR) yang mengakibatkan vasodilatasi, hipotensi, dan bradikardia. ${ }^{3,4,8,9}$

Intervensi yang dilakukan untuk mencegah hipotensi akibat anestesi spinal, yaitu meningkatkan volume intravaskular dengan preloading, pemberian obat-obatan, mengurangi dosis obat anestesi lokal, mekanikal seperti elevasi kaki, membungkus kaki, memposisikan uterus. Pemberian obatobatan untuk mencegah hipotensi, yaitu pemberian vasopresor dan antagonis reseptor 5HT3. ${ }^{1,7,10}$

Pemberian cairan masih dianggap sebagai tindakan yang aman dan efektif untuk mencegah hipotensi akibat anestesi spinal, akan tetapi pemberian cairan memiliki efek samping seperti kelainan koagulasi ringan, pruritus, dan potensi reaksi alergi terhadap larutan koloid. Pemberian obat vasopresor untuk pencegahan hipotensi dapat menyebabkan hipertensi dan disritmia pada ibu terutama pada ibu hamil yang mengalami hipertensi dalam kehamilan, misalnya preeklamsia. Selain itu, obat vasopresor dapat menyebabkan vasokonstriksi pembuluh darah uterus dan pembuluh darah plasenta yang dapat mengganggu oksigenasi janin. Metode lain seperti elevasi kaki, membungkus kaki serta memposisikan kepala lebih rendah selain tidak nyaman bagi pasien, juga efektivitasnya untuk pencegahan hipotensi masih perlu penelitian lebih lanjut. ${ }^{1,7,9,10,11}$

Beberapa penelitian menyatakan bahwa reseptor 5HT3 memiliki peran penting dalam terjadinya BJR pada keadaan penurunan volume darah secara tiba-tiba. Efek ini dapat diblok dengan antagonis reseptor 5HT3 sehingga kejadian hipotensi pada pasien obstetrik yang yang akan dilakukan seksio sesarea dengan anestesi spinal dapat diminimalisir. ${ }^{3,4,7}$

Granisetron merupakan suatu antagonis reseptor 5HT3 dapat mencegah serotonin untuk memengaruhi terjadi BJR sehingga mengurangi terjadi dilatasi pembuluh vena, mengembalikan aliran balik vena ke jantung, dan mengurangi kejadian penurunan tekanan darah sistol dan tekanan arteri rerata. ${ }^{3,4}$

Tujuan penelitian ini adalah mengkaji pengaruh pemberian granisetron intravena prainduksi terhadap besar penurunan tekanan darah pada seksio sesarea dengan anestesi spinal.

\section{Subjek dan Metode}

Penelitian ini mempergunakan metode eksperimental analitik komparatif kategorik numerik dengan desain double blind 
randomized clinical controlled trial. Subjek penelitianadalah pasienyangmenjalanioperasi seksio sesarea dengan anestesi spinal di RSUP Dr. Hasan Sadikin Bandung. Pemilihan subjek penelitian berdasar atas kriteria inklusi, yaitu usia 18-45 tahun, status fisik American Society of Anesthesiologists (ASA) kategori II, body mass index (BMI) $25-34 \mathrm{~kg} / \mathrm{m}^{2}$ yang bersedia mengikuti penelitian dan menandatangani persetujuan (informed consent). Kriteria eksklusi adalah kehamilan gemeli, bayi besar, polihidroamnion, serta riwayat alergi terhadap obat-obat yang digunakan pada penelitian. Kriteria pengeluaran adalah anestesi spinal gagal, blok anestesi spinal kurang dari torakal 6 atau lebih dari torakal 5, tindakan anestesi spinal berubah menjadi anestesi umum, dan perdarahan yang lebih dari $1.000 \mathrm{~mL}$.

Penentuan jumlah sampel menggunakan formula perhitungan besar sampel pada penelitian analitik komparatif kategorik numerik tidak berpasangan dan didapatkan jumlah sampel minimal 17 pasien untuk tiaptiap kelompok. Pengambilan sampel dilakukan secara consecutive sampling dan dilakukan randomisasi subjek ke dalam dua kelompok penelitian dengan metode randomisasi blok permutasi. Subjek penelitian dibagi menjadi dua kelompok, yaitu kelompok granisetron mendapat granisetron intravena dan kelompok kontrol mendapat $\mathrm{NaCl}$ 0,9\%. Penelitian dilakukan di RSUP Dr. Hasan Sadikin Bandung, pada bulan Desember 2019-Februari 2020 setelah mendapat persetujuan dari Komite Etik Penelitian Kesehatan RSUP Dr. Hasan Sadikin Nomor LB.02.01/X.6.5/332/2019.

Pasien yang sesuai kriteria inklusi dan tidak termasuk kriteria eksklusi serta telah manandatangani persetujuan (informed consern) dijadikan sebagai subjek penelitian. Pasien pada kedua kelompok dipuasakan selama 6 jam dengan pemberian cairan rumatan Ringer laktat $2 \mathrm{cc} / \mathrm{kgBB} / \mathrm{jam}$.

Setelah masuk ke kamar operasi, pasien dipasang alat untuk memantau tekanan darah noninvasif, elektrokardiogram dan saturasi oksigen, kemudian diberikan oksigen melalui nasal kanul 3 liter/menit. Pasien kemudian dilakukan pemeriksaan tekanan darah, laju nadi, laju napas, dan saturasi untuk mengetahui baseline hemodinamik awal.

Pasien kemudian dilakukan preloading dengan cairan Ringer laktat sebanyak $10 \mathrm{cc} /$ kgBB selama 15 menit. Pasien kelompok G diberikan granisetron $1 \mathrm{mg}$ intravena yang diencerkan menjadi $10 \mathrm{cc}$, sedangkan pada kelompok C diberikan $\mathrm{NaCl}$ 0,9\% sebanyak 10 cc dalam spuit 10 cc yang diberikan perlahan selama satu menit.

Anestesi spinal dilakukan setelah 5 menit pemberian granisetron/ $\mathrm{NaCl} 0,9 \%$. Anestesi spinal menggunakan bupivacain hiperbarik 10 mg dan fentanil $25 \mu \mathrm{g}$. Ketinggian blok sensoris dinilai dengan tes pinprick. Pengukuran level blok dilakukan setiap menit sampai dengan 15 menit setelah penyuntikan anestesi spinal dengan target ketinggian blok setinggi torakal 6 hingga torakal 5. Bila setelah 15 menit tidak didapatkan blok anestesi maka anestesi spinal dianggap gagal dan pasien dikeluarkan dari penelitian. Tindakan seksio sesarea dilakukan setelah anestesi spinal dinyatakan berhasil. Setelah bayi lahir kemudian ibu diberikan oksitosin drip 20 IU dalam $500 \mathrm{NaCl}$ 0,9\% sebanyak 10-15 tetes per menit. Selama tindakan operasi pasien tidak diberikan sedasi.

Pengukuran tekanan darah sistole, diastole, MAP, laju nadi, laju napas, dan saturasi oksigen dilakukan setiap 1 menit pada 20 menit pertama setelah dilakukan anestesi spinal kemudian setiap 2,5 menit sampai operasi selesai. Pemberian efedrin bolus intravena 5 mg dilakukan jika pasien mengalami hipotensi, yaitu penurunan tekanan darah sistole $>20 \%$ dari nilai awal. Bradikardia akan diterapi dengan sulfas atropin $0,5 \mathrm{mg}$ intravena. Pasien yang mengalami mual muntah diberikan metoclopramide $10 \mathrm{mg}$ intravena. Pencatatan dilakukan terhadap jumlah efedrin, sulfas atrofin, dan obat-obatan yang diberikan selama intraoperasi.

Uji statistik menggunakan uji t dan Uji Mann Whitney pada data numerik. Uji statistik pada data kategorik menggunakan uji chi-square dengan alternatif Uji Kolmogorov-Smirnov. Adapun kriteria kemaknaan ditentukan dengan dengan $\mathrm{p} \leq 0,05$ dianggap signifikan atau bermakna secara statistika. Data hasil 
Tabel 1 Karateristik Subjek Penelitian

\begin{tabular}{lccc}
\hline \multirow{2}{*}{ Variabel } & \multicolumn{2}{c}{ Kelompok } & \multirow{2}{*}{ Nilai p } \\
\cline { 2 - 3 } & Kontrol (n=17) & Granisetron (n=17) & \\
\hline Usia (tahun), mean \pm SD & $27,88 \pm 7,158$ & $30,65 \pm 7,271$ & 0,272 \\
Tinggi badan (cm), mean \pm SD & $156,71 \pm 4,740$ & $157,18 \pm 3,005$ & 0,708 \\
Berat badan (kg), mean \pm SD & $69,76 \pm 10,189$ & $73,76 \pm 7,259$ & 0,140 \\
Lama puasa (jam), mean \pm SD & $6,65 \pm 0,931$ & $6,88 \pm 1,054$ & 0,474 \\
BMI (kg/m²), mean \pm SD & $28,30 \pm 2,960$ & $29,84 \pm 2,580$ & 0,116 \\
Lama operasi (menit), mean $\pm S D$ & $62,94 \pm 9,691$ & $65,29 \pm 10,227$ & 0,496 \\
Perdarahan (mL), mean \pm SD & $438,24 \pm 131,731$ & $432,94 \pm 100,048$ & 0,919 \\
Cairan intraoperasi (mL), mean \pm SD & $1088,24 \pm 257,105$ & $1005,88 \pm 241,015$ & 0,274 \\
Tinggi Blok, n & & & 0,656 \\
T5 & 4 & 2 & \\
T6 & 13 & 15 & \\
\hline
\end{tabular}

Keterangan: untuk data numerik nilai p diuji dengan uji T tidak berpasangan apabila data berdsitribusi normal dengan alternatif Uji Mann Whitney apabila data tidak berdistribusi normal. Data kategorik nilai p dihitung berdasarkan uji Chi-Square dengan alternatif Uji Kolmogorov-Smirnov dan Exact Fisher apabila syarat chi-square tidak terpenuhi. Nilai kemaknaan berdasar atas nilai $\mathrm{p}<0,05$. Tanda* menunjukkan nilai $\mathrm{p}<0,05$ artinya signifkan atau bermakna secara statistik

penelitian dicatat dan diolah menggunakan program statistical product and service solution (SPSS) versi 24.0 for windows.

\section{Hasil}

Gambaran karakteristik subjek penelitian antara kelompok kontrol dan kelompok granisetron berdasar atas usia, tinggi badan, berat badan, BMI, lama puasa, lama operasi, jumlah perdarahan, cairan intraoperasi dan ketinggian blok anestesi spinal tidak terdapat perbedaan signifikan ( $p>0,05$; Tabel 1).

Penurunan tekanan darah sistole rerata pada kelompok kontrol lebih besar dibanding dengan kelompok granisetron. Analisis

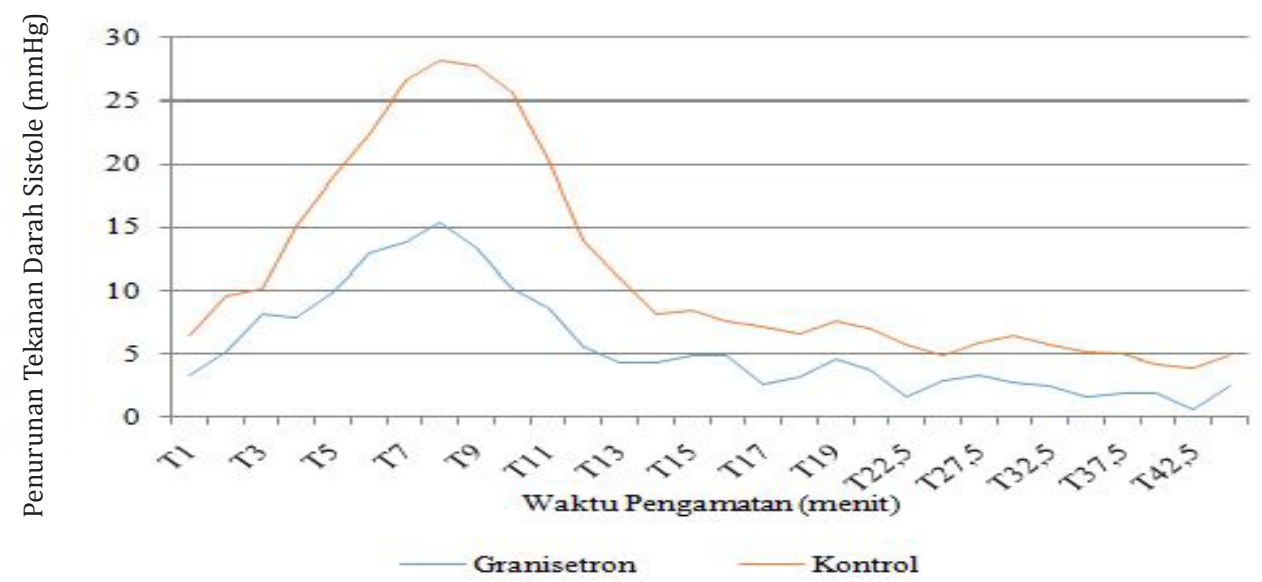

Gambar 1 Perbandingan Penurunan Tekanan Darah Sistole antara Kelompok Kontrol dan Kelompok Granisetron 


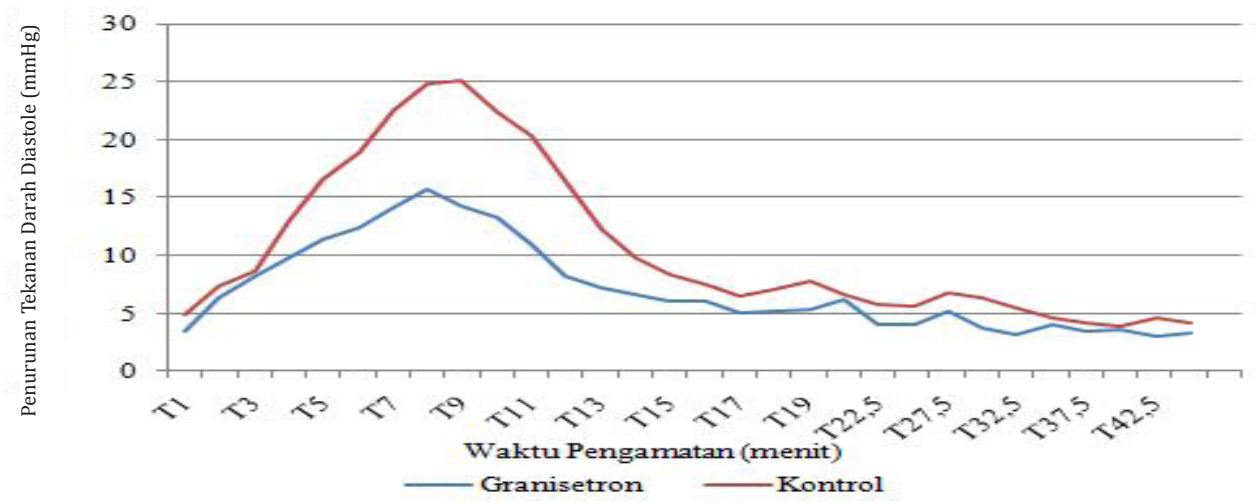

Gambar 2 Perbandingan Penurunan Tekanan Darah Diastole antara Kelompok Kontrol dan Kelompok Granisetron

statistik dengan uji-t tidak berpasangan menunjukkan perbedaan bermakna $(\mathrm{p} \leq 0,05)$ pada menit ke-1, ke-2, ke-4, ke-5, ke-6, ke-7, ke-8, ke-9, ke-10, ke-11, ke-12, ke-13, dan ke17 (Gambar 1).

Penurunan tekanan darah diastole pada kelompok kontrol lebih besar dibanding dengan kelompok granisetron. Analisis statistik dengan uji-t tidak berpasangan menunjukkan perbedaan bermakna $(p \leq 0,05)$ pada menit ke-8, ke-9, ke-10, ke-11, ke-12, ke13, dan ke-32,5 (Gambar 2).

Penurunan mean arterial pressure (MAP) pada kelompok kontrol lebih besar dibanding dengan kelompok granisetron. Analisis statistik dengan uji-t tidak berpasangan menunjukkan perbedaan signifikan $(\mathrm{p} \leq 0,05)$ pada menit ke-1, ke-2, ke-4, ke-5, ke-6, ke-7, ke-8, ke-9, ke-10, ke-11, ke-12, ke-13, ke-14, ke-16, ke-17, ke-18, ke-19, ke-22,5; ke-27,5; dan ke-30 (Gambar 3).

Analisis statistik terhadap perbandingan laju nadi antara kelompok kontrol dan kelompok granisetron sebelum dan setelah anestesi spinal mempergunakan uji-t tidak berpasangan menunjukkan tidak terdapat perbedaan bermakna ( $p \geq 0,05$; Gambar 4). Pada pemantauan laju nadi tidak didapatkan pasien yang mengalami bradikardia.

Subjek yang mengalami kejadian hipotensi (penurunan tekanan darah sistole $>20 \%$ ) sebanyak 5 orang pada kelompok granisetron dan 13 orang pada kelompok kontrol. Jumlah efedrin yang diberikan pada kelompok kontrol lebih banyak dibanding dengan kelompok granisetron dengan perbedaan bermakna ( $\mathrm{p}<0,005$; Tabel 2).

Pada penelitian ini kejadian mual lebih

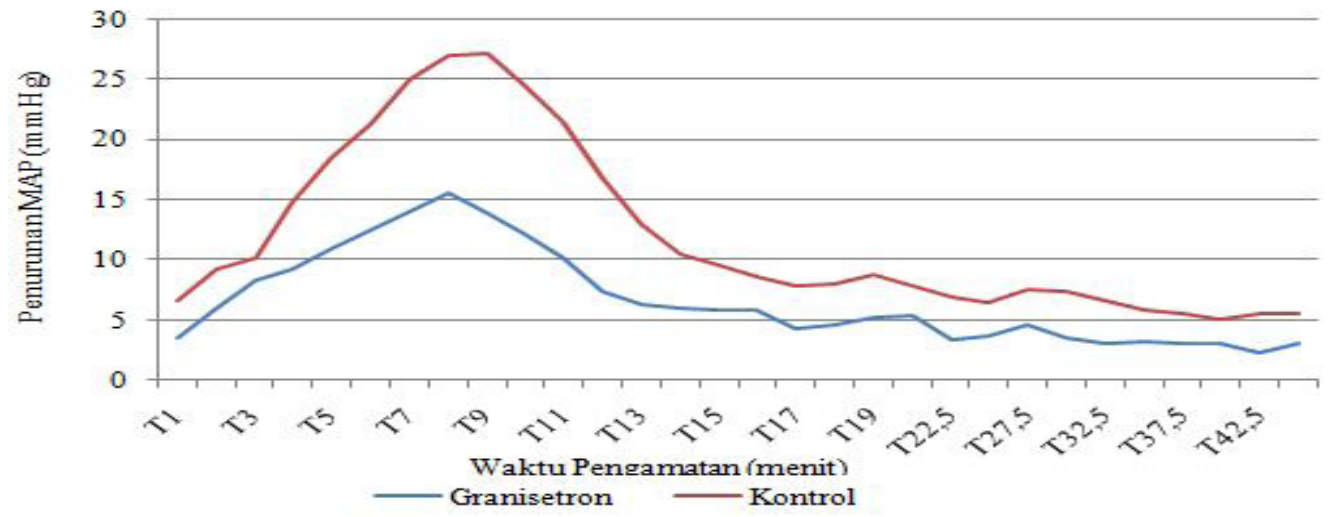

Gambar 3 Perbandingan Penurunan Mean Arterial Pressure Rerata antara Kelompok Kontrol dan Kelompok Granisetron 


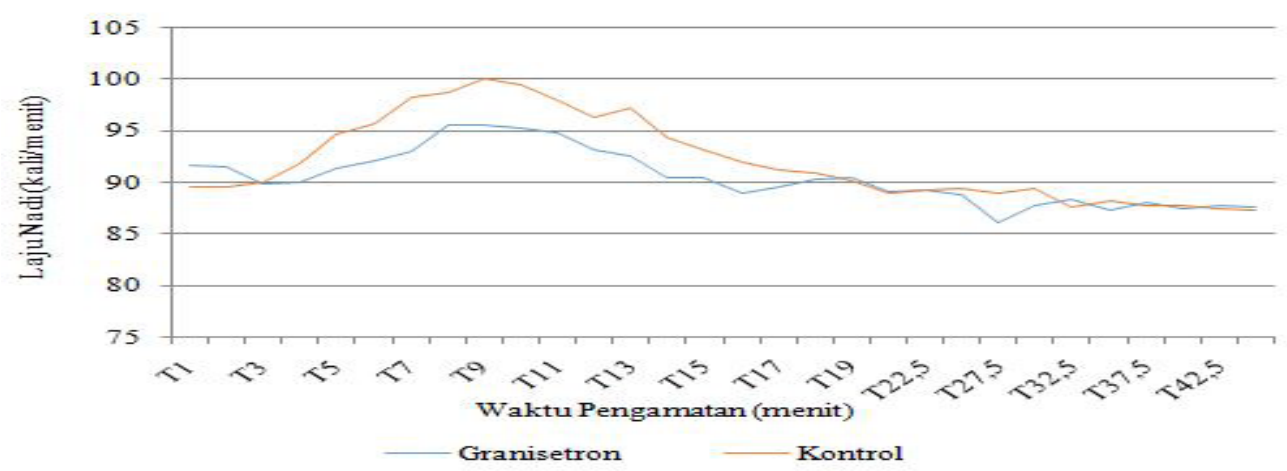

Gambar 4 Perbandingan Laju Nadi antara Kelompok Kontrol dan Kelompok Granisetron

Tabel 2 Perbandingan Kejadian Hipotensi dan Pemberian Efedrin antara Kelompok Kontrol dan Kelompok Granisetron

\begin{tabular}{lccc}
\hline \multicolumn{1}{c}{ Variabel } & Granisetron & Kontrol & Nilai p \\
\hline Hipotensi, (n) & 5 & 13 & $0,005^{*}$ \\
Pemberian efedrin, (n) & 5 & 13 & $0,005^{*}$ \\
Total pemakaian efedrin, $($ mean \pm SD) & $5,00 \pm 00$ & $8,08 \pm 4,35$ & $0,002^{*}$ \\
\hline
\end{tabular}

Keterangan: nilai $\mathrm{p}^{*}$ ) dihitung berdasar atas Uji Mann-Whitney. Nilai p bermakna $(\mathrm{p}<0,05)$

banyak dirasakan pada kelompok kontrol sebanyak 5 dari 17 orang dibanding dengan dengan kelompok granisetron sebanyak 1 orang.

\section{Pembahasan}

Subjek penelitian ini terdiri atas 34 pasien dengan karakteristik subjek berdasar atas usia, tinggi badan, berat badan, BMI, lama puasa, lama operasi, jumlah perdarahan, cairan intraoperasi, dan ketinggian blok anestesi spinal antara kedua kelompok tidak menunjukkan perbedaan bermakna $(p>0,05)$. Hal ini menunjukkan bahwa sampel yang dibandingkan dalam penelitian ini relatif homogen dan layak dibandingkan.

Hasil penelitian ini diperoleh bahwa penurunan tekanan darah pada kelompok kontrol lebih besar bila dibanding dengan kelompok granisetron dan kejadian hipotensi (penurunan tekanan darah sistole $>20 \%$ ) pada kelompok kontrol lebih banyak dibanding dengan kelompok granisetron. Hasil tersebut menunjukkan bahwa pemberian granisetron sebelum dilakukan tindakan anestesi spinal pada seksio sesarea dapat mengurangi besar penurunan tekanan darah dibanding dengan kelompok kontrol.

Hipotensi merupakan komplikasi paling sering pada seksio sesarea dengan anestesi spinal disebabkan oleh blokade simpatis yang menyebabkan penurunan SVR dan mengakibatkan pooling cairan pada perifer. Penurunan aliran darah balik ke jantung yang diakibatkan anestesi spinal sehingga menyebabkan penurunan curah jantung. ${ }^{1,12}$

Hipotensi pada seksio sesarea diperberat oleh perubahan fisiologis wanita hamil, yaitu penurunan SVR, penurunan aliran balik darah ke jantung, penekanan vena kava oleh uterus, dan pembentukan sirkulasi kolateral di ruang epidural. ${ }^{1,7}$ Preload jantung yang menurun secara tiba-tiba pada anestesi spinal mengakibatkan rangsangan pada cardiac sensory receptor menyebabkan bezold jarisch reflex (BJR). Bezold jarisch reflex (BJR) berfungsi menghambat perangsangan pada pusat vasomotor yang menghambat aliran simpatis sehingga terjadi bradikardia, vasodilatasi perifer, dan hipotensi. Reseptor BJR terletak di dinding ventrikel, baik 
bersifat mechanosensitive dan chemosensitive. Sinyal aferen melalui komponen saraf vagus unmyelinated. ${ }^{9}$

Granisetronadalahantagonis reseptor 5HT3 yang berperan mencegah BJR. BJR merupakan cardioinhibitory reflex sebagai akibat respons hipovolemia relatif, saraf aferen unmylenated dari dinding inferoposterior ventrikel kiri melalui saraf glossopharyngeal dan vagus ke batang otak merespons penurunan aliran balik vena. ${ }^{13}$ Hipovolemia relatif dan penurunan preload jantung akibat anestesi spinal menyebabkan pelepasan serotonin yang menstimulasi cardiac sensory receptor di ventrikel jantung. Stimulasi pada cardiac sensory receptor menyebabkan BJR sehingga terjadi vasodilatasi perifer, bradikardia, dan hipotensi. ${ }^{3,4}$

Granisetron secara kompetitif memblokir aksi serotonin pada cardiac sensory receptor yang merupakan reseptor 5HT3 sehingga tidak terjadi peningkatan aktivitas nervus vagal eferen yang menyebabkan BJR. ${ }^{14}$ Granisetron memiliki onset 1-3 menit setelah pemberian intravena sehingga pemberian granisetron sebelum anestesi spinal dapat mencegah aktivasi BJR akibat hipovolemia relatif akibat anestesi spinal mengurangi vasodilatasi serta kejadian penurunan tekanan darah. ${ }^{3,4,9,14}$

Pada penelitian ini tidak didapatkan perbedaan kondisi klinis yang signifikan antara kedua kelompok, walaupun secara statistik bermakna. Pada penelitian ini tidak didapatkan keadaan hipotensi berat dan perbedaan penurunan tekanan darah yang tidak terlalu jauh antara kedua kelompok. Hal ini dikarenakan pada kedua kelompok telah diberikan cairan preloading Ringer laktat. Pemberian cairan preloading kristaloid pada anestesi spinal merupakan salah satu tindakan tata laksana dalam mencegah hipotensi. ${ }^{1,7,10,11,15}$

Penggunaan antagonis reseptor 5HT3 sebelum tindakan anestesi spinal dapat mengurangi penggunaan dan pemberian obat-obat vasopresor pada seksio sesarea dengan anestesi spinal. Hasil penelitian ini sesuai dengan penelitian pada tahun 2015 di RSUP dr. Hasan Sadikin menggunakan ondansetron sebagai antagonis reseptor
5HT3 dapat mengurangi penurunan tekanan darah sistole dan juga tekanan darah rerata, serta penggunaan efedrin pada seksio sesarea dengan anestesi spinal. ${ }^{14}$ Hasil ini juga sesuai dengan dua penelitian lain bahwa pemberian granisetron $1 \mathrm{mg}$ efektif dapat menurunkan angka kejadian hipotensi serta mengurangi penggunaan obat vasopresor pada seksio sesarea dengan anestesi spinal. ${ }^{4,16}$

Dari hasil penelitian didapatkan juga perbedaan yang signifikan antara kelompok kontrol dan kelompok granisetron pada pemakaian obat vasopresor efedrin. Saat ini, penggunaan vasopresor merupakan metode yang paling diterima secara luas untuk tata laksana penanganan hipotensi setelah anestesi spinal. ${ }^{5,17}$

Pemberian granisetron sebelum tindakan seksio sesarea juga memiliki efek samping yang minimal baik pada ibu dan pada janin. Efek samping yang paling sering didapatkan berupa sakit kepala dan konstipasi yang umumnya ringan. ${ }^{18}$ Konsentrasi granisetron pada janin ditemukan minimal. ${ }^{19}$

Pada penelitian ini didapatkan kejadian mual lebih banyak terjadi pada kelompok kontrol sebanyak 5 dari 17 pasien dibanding dengan kelompok granisetron sebanyak 1 dari 17 pasien. Hal ini memang sesuai penelitian terdahulu terkait pemberian granisetron sebagai antiemetik dan antimuntah pada seksio sesarea dengan anestesi spinal. ${ }^{20}$

Tidak didapatkan perubahan laju nadi yang bermakna antara kelompok kontrol dan kelompok granisetron dengan tidak didapatkan juga kejadian bradikardia pada kedua kelompok. Kejadian bradikardia itu merupakan salah satu petanda BJR.,4 Pada penelitian ini tidak didapatkan kejadian bradikardia karena pemberian cairan rumatan dan preloading kristaloid mencegah penurunan aliran darah balik yang tibatiba sehingga BJR dapat dicegah. Pemberian efedrin pada saat terjadi hipotensi juga memberikan efek meningkatkan laju nadi pada kedua kelompok. Pada penelitian sebelumnya baik menggunakan ondansetron maupun granisetron, tidak didapatkan perubahan laju nadi yang bermakna. ${ }^{3,4,14}$ 
Keterbatasan penelitian ini tidak dihitung lingkar perut pasien dan berat badan janin sehingga perbedaan lingkar perut dan berat badan janin dapat memengaruhi besar penurunan tekanan darah yang diakibatkan penekanan uterus. Selain itu, pada penelitian ini tidak dihitung waktu insisi dan interval waktu bayi lahir sehingga besar hipotensi terjadi apakah sebelum bayi lahir atau sesudah bayi lahir.

\section{Simpulan}

Pemberian granisetron $1 \mathrm{mg}$ secara intravena prainduksi ternyata dapat mengurangi besar penurunan tekanan darah rerata pada seksio sesarea dengan anestesi spinal.

\section{Daftar Pustaka}

1. Lawrence C, Tsen M. Anesthesia for cesarean delivery. Dalam: David $\mathrm{H}$, Chestnut M, Cynthia A, Wong M, Lawrence $\mathrm{C}$, Tsen M, dkk., penyunting. Chestnut's obstetric anesthesia: principles and practice. Edisi ke-5. Philadelphia: Elsevier Inc.; 2014. hlm. 545-603.

2. Armstrong S. Spinal anesthesia for cesarean section. Dalam: Capogna G, penyunting. Anesthesia for cesarean section. Edisi ke-1. Switzerland: Springer International Publishing; 2017. hlm. 4766.

3. Eldaba AA, Amr YM. Intravenous granisetron attenuates hypotension during spinal anesthesia in cesarean delivery: a double-blind, prospective randomized controlled study. J Anaesthesiol Clin Pharmacol. 2015;31(3):329-32.

4. Abdalla W, Ammar M. Systemic granisetron can minimize hypotension and bradycardia during spinal anesthesia in patients undergoing elective lower-abdominal surgeries: a prospective, double-blind randomized controlled study. Ain-Shams J Anaesthesiol. 2017;10(1):247-52.

5. Hasanin A, Mokhtar AM, Badawy AA, Fouad R. Post-spinal anesthesia hypotension during cesarean delivery, a review article.
Egypt J Anaesth. 2017;33(2):189-93.

6. Rustini R, Fuadi I, Surahman E. Insidensi dan faktor risiko hipotensi pada pasien yang menjalani seksio sesarea dengan anestesi spinal di Rumah Sakit Dr. Hasan Sadikin Bandung. JAP. 2016;4(1):42-9.

7. Lee JE, George RB, Habib AS. Spinalinduced hypotension: incidence, mechanisms, prophylaxis, and management: summarizing 20 years of research. Best Pract Res Clin Anaesthesiol. 2017;31(1):57-68.

8. Warren DT, Nelson KE, Neal JM. Neuraxial anesthesia. Dalam: Longnecker DE, Sandberg WS, Mackey SC, Zapol WM, Newman MF, penyunting. Anesthesiology. Edisi ke-3. New York: McGraw-Hill Education; 2018. hlm. 727-48.

9. Heesen M, Klimek M, Hoeks SE, Rossaint R. Prevention of spinal anesthesia-induced hypotension during cesarean delivery by 5-hydroxytryptamine-3 receptor antagonists: a systematic review and metaanalysis and meta-regression. Anesth Analg. 2016;123(4):977-88.

10. Chooi C, Cox JJ, Lumb RS, Middleton P, Chemali M, Emmett RS, dkk. Techniques for preventing hypotension during spinal anaesthesia for caesarean section. Cochrane Database Syst Rev. 2017;8(8):CD002251.

11. Jain P, Valecha D. Comparative evaluation of preloading and coloading of crystalloids to prevent spinal induced hypotension in caesarean section. Int J Contemp Med Res. 2017;4(2):411-4.

12. Abe H, Sumitani M, Uchida K, Ikeda T, Matsui H, Fushimi K, dkk. Association between mode of anaesthesia and severe maternal morbidity during admission for scheduled caesarean delivery: a nationwide population-based study in Japan, 20102013. Br J Anaesth. 2018;120(4):779-89.

13. Sinisa Š, Kresmir O. Sudden cardiorespiratory arrest following spinal anesthesia. Periodic Biologorum. 2013; 115(2):283-8.

14. Ismandiya AI, Maskoen TT, Sitanggang RH. Efek ondansetron intravena terhadap 
tekanan darah dan laju nadi pada anestesi spinal untuk seksio sesarea. JAP. 2015;3(2):73-80.

15. Braveman FR, Scavone BM, Blessing ME, Wong CA. Obstetric anesthesia. Dalam: Barash PG, Cullen BF, Stoelting RK, Cahalan MK, Stock MC, Ortega R, dkk., penyunting. Clinical anesthesia. Edisi ke-8. Philadelphia: Wolters Kluwer; 2017. hlm. 2841-926.

16. Paulraj S, Sundararajan L, Ali AA. Intravenous granisetron attenuates hypotension during spinal anaesthesia in cesarean delivery: a double-blind, prospective randomized controlled study. Indian J Appl Res. 2018;8(3):13-5.

17. Kinsella SM, Carvalho B, Dyer RA, Fernando R, Mcdonnell N, Mercier FJ, dkk. International consensus statement on the management of hypotension with vasopressors during caesarean section under spinal anaesthesia. Anaesthesia. 2018;73(1):71-92.

18. Spartinou A, Nyktari V, Papaioannou A. Granisetron: a review of pharmacokinetics and clinical experience in chemotherapy induced-nausea and vomiting. Expert Opin Drug Metab Toxicol. 2017;13(12):128997.

19. Julius JM, Tindall A, Moise KJ, Refuerzo JS, Berens PD, Smith JA. Evaluation of the maternal-fetal transfer of granisetron in an ex vivo placenta perfusion model. Reprod Toxicol. 2014;49:43-7.

20. Sharma S, Singh M. Efficacy of granisetron for prevention of nausea and vomiting in patients undergoing cesarean section under spinal anesthesia: a randomized double blind placebo-controlled study. J Advan Med Dental Sci Res. 2019;7(1):1525. 